\title{
HUBUNGAN EKSPRESI HER2 DENGAN UKURAN TUMOR DAN INVASI KAPSULAR PAPILLARY THYROID CARCINOMA (PTC)
}

\author{
Griesinta Trianty Andria Pinahayu ${ }^{* \otimes}$, Diah Prabawati Retnani ${ }^{*}$, Kenty Wantri Anita*, \\ Harun Al Rasyid ${ }^{* *}$, Hery Susilo***
}

\begin{abstract}
Abstrak
Papillary thyroid carcinoma (PTC) merupakan karsinoma tersering pada tiroid yang secara klinis dapat menyerupai lesi jinak. PTC subtipe ocult tidak jarang ditemukan bermetastase pada kelenjar getah bening (KGB) atau organ lain. Faktor prognosis pada pasien PTC ditentukan oleh subtipe histologi, ukuran tumor, usia, jenis kelamin, metastase dan invasi kapsular, dengan angka kekambuhan cukup tinggi, yaitu $20 \%$. Human Epidermal Growth Factor Receptor 2 (HER2) adalah anggota Epithelial Growth Factor Receptor (EGFR), yang menunjukkan ekspresi kuat pada keganasan sel epitel manusia. Penelitian ini bertujuan untuk melihat hubungan ekspresi HER2 dengan ukuran tumor dan invasi kapsular PTC. Pemeriksaan histopatologi dan imunohistokimia HER2 dilakukan pada 54 sampel, 27 dengan invasi kapsular dan 27 tanpa invasi kapsular, kemudian diukur besar tumor, interpretasi ekspresi HER2, lalu ditabulasi dan dianalisis hubungan ekspresi HER2 dengan ukuran tumor dan invasi kapsular PTC. Ekspresi HER2 pada penelitian ini didapatkan pada 10 sampel HER2 skor 3+, 22 sampel skor 2+, 14 sampel skor 1+, dan 8 sampel skor 0 . Hubungan antara ekspresi HER2 dengan invasi kapsular PTC, dianalisis dengan Mann Whitney test, didapatkan hasil bermakna $(p=0,002)$. Dengan uji korelasi Spearman, didapatkan korelasi lemah terbalik (koefisien korelasi -.299) tapi bermakna $(p=0,028)$ antara ekspresi HER2 dengan ukuran tumor PTC. Terdapat hubungan ekspresi HER2 dengan invasi kapsular, dan hubungan lemah berbanding terbalik antara ekspresi HER2 dengan ukuran tumor yaitu semakin besar ukuran tumor semakin rendah skor HER2 dan sebaliknya.
\end{abstract}

Kata Kunci: HER2, invasi kapsular PTC, ukuran tumor PTC.

\section{RELATIONSHIP BETWEEN HER2 EXPRESSION WITH TUMOR SIZE AND CAPSULAR INVASION OF PAPILLARY THYROID CARCINOMA (PTC)}

\begin{abstract}
Papillary thyroid carcinoma (PTC) is the most common carcinoma in thyroid, clinically resembling benign lesions. PTC including ocult subtype often metastases in lymph nodes or other organs. Prognostic factors of PTC include histology subtype, tumor size, age, gender, metastases and capsular invasion. The PTC recurrence rate is high at 20\%. Human Epidermal Growth Factor Receptor 2 (HER2) is a member of Epithelial Growth Factor Receptor (EGFR), overexpress in human epithelial malignancies. This study aimed to determine HER2 expression relation with PTC tumor size and capsular invasion. Histopathological examination and HER2 immunohistochemistry were conducted in 54 samples, 27 capsular invasion and 27 without capsular invasion, measurements of tumor size, interpretation of HER2 expression. The data were tabulated and the relation of HER2 expression with tumor size and capsular invasion was analyzed. In this study, there were 10 samples of HER2 score 3+, 22 samples score 2+, 14 samples score 1+, and 8 samples score 0 . The relation between HER2 expression and PTC capsular invasion, analyzed with the Mann Whitney test, obtained significant results $(p=0.002)$. Spearman correlation test showed a weak inverse correlation (correlation coefficient -.299) but significant $(p=0.028)$ between HER2 expression and PTC tumor size. In this study, there was a relation between HER2 expression and capsular invasion, and a inversely weak correlation between HER2 expression and tumor size that is, the larger the tumor size the lower the HER2 score and vice versa.
\end{abstract}

Keywords: HER2, PTC capsular invasion, PTC tumor size.

* Departemen Patologi Anatomi, Fakultas Kedokteran, Universitas Brawijaya

** Departemen IImu Kesehatan Masyarakat dan Kedokteran Pencegahan, Fakultas Kedokteran, Universitas Brawijaya

*** Departemen Bedah, Fakultas Kedokteran, Universitas Brawijaya-RSUD Dr. Saiful Anwar Malang

E-mail: dr.griesinta@gmail.com 


\section{Pendahuluan}

Papillary thyroid carcinoma (PTC) merupakan keganasan epitelial tersering pada tiroid. Data dari American Cancer Society pada tahun 2017 terdapat 56.870 kasus baru karsinoma tiroid, dengan 2010 kasus mengalami kematian. Dari 56.870 kasus tersebut, sebanyak $74-80 \%$ adalah PTC. ${ }^{1}$ Berdasarkan data di Amerika tahun 2015, terdapat peningkatan kasus kanker tiroid yaitu $90 \%$ kasus merupakan PTC. ${ }^{2}$ Data yang diperoleh dari registrasi Perhimpunan Dokter Spesialis Patologi Indonesia pada tahun 2014 memperlihatkan bahwa kanker tiroid menempati urutan ke-6 dari 10 kanker terbanyak berdasarkan tumor primer. Kanker tiroid juga menempati urutan tumor primer ke4 dari 10 tumor tersering pada wanita. Di Malang, kanker tiroid merupakan kanker primer tersering nomor 9, termasuk di antaranya PTC. ${ }^{3}$

PTC klasik memiliki gambaran khas yaitu inti yang terdapat grooves, pseudoinclusion, dan ground glass appearance, psammoma bodies serta bentukan papiler. Gambaran ini menjadi dasar untuk penegakkan diagnosa PTC. Berdasarkan WHO 2017, PTC secara histologis mempunyai 14 varian/subtipe, di antaranya adalah occult, collumnar, tall cell, follicular, solid, encapsulated dan oncocytic. Secara klinis PTC dapat menyerupai lesi jinak, terutama subtipe occult. Pada tumor yang berukuran $<1 \mathrm{~cm}$ sering didapat metastase pada kelenjar getah bening (KGB) atau organ lain. Faktor yang berpengaruh pada prognosis pasien PTC di antaranya adalah subtipe histologi, ukuran tumor, usia pasien, jenis kelamin. Meskipun diketahui bahwa 95\% kasus PTC memberi respons terhadap terapi, namun angka kekambuhan PTC cukup tinggi yaitu sebesar $20 \% .{ }^{4}$

HER2 termasuk anggota Epithelial Growth Factor Receptor (EGFR), yang menunjukkan ekspresi kuat pada keganasan sel epitel manusia. HER2 termasuk dalam protein onkogen, satu famili dengan Epidermal Growth Factor Receptor (EGFR) dengan aktivitas tyrosin kinase, mengkode reseptor glikoprotein transmembran yang ada pada sel normal dan berperan penting dalam aktivitas biologis sel seperti proliferasi, differensiasi, transformasi, dan inhibisi apoptosis. Overekspresi dari HER2 menunjukkan sifat yang agresif. HER2 yang positif juga menggambarkan tumor tersebut dapat sebagai target obat antineoplastik spesifik (Herceptin/tranztuzumab). Penelitian tentang HER2 telah banyak dilakukan pada kanker berbagai organ, di antaranya karsinoma payudara dan karsinoma kolorektal. 5 Pada tahun 2004, Kato menemukan adanya ekspresi HER2 pada PTC. ${ }^{5}$ Namun Balta pada tahun 2007 dan Kim pada tahun 2018 mengemukakan bahwa tidak terdapat korelasi yang kuat antara ekspresi HER2 dengan faktor prognostik, seperti ukuran tumor, subtipe, metastase pada KGB.6,7 Hasil penelitian lain oleh Mohapatra pada tahun 2019 dan Rabiee pada tahun 2017 menyebutkan bahwa ada hubungan antara ekspresi HER2 dengan ukuran tumor dan invasi kapsular PTC, namun jumlah sampel antara kelompok invasi kapsular dan tanpa kapsular tidak setara dengan selisih yang jauh. Pada penelitian Rabiee pada tahun 2017 yaitu hanya terdapat 6 kasus tanpa invasi kapsular dari total 85 kasus. Jumlah sampel penelitian Mohapatra pada tahun 2019 adalah 25 sampel dengan 20 sampel tanpa invasi kapsular.8,9 Delia pada tahun 2017 menemukan bahwa HER2 menunjukkan ekspresi yang berbeda pada variasi subtipe histologi PTC.10 Penelitianpenelitian yang telah dilakukan tersebut masih terdapat kontradiksi, sehingga masih diperlukan penelitian lebih lanjut mengenai hubungan HER2 terhadap ukuran tumor dan invasi kapsular sebagai faktor prognosa PTC. 
Penelitian ini bertujuan untuk melihat bagaimana ekspresi HER2 pada PTC, serta adakah hubungan ekspresi HER2 dengan ukuran tumor dan invasi kapsular PTC. Pada penelitian ini jumlah sampel kelompok dengan invasi kapsular dan tanpa invasi kapsular sama besar untuk dilakukan uji beda yang valid. Adanya pengetahuan tentang hubungan ekspresi HER2 dengan ukuran tumor dan invasi kapsular PTC diharapkan dapat menjadi dasar penggunaan pemeriksaan imunohistokimia dengan antibodi HER2 sebagai modalitas diagnosa dan prognostik PTC.

\section{Bahan dan Metode}

\section{Desain Penelitian}

Penelitian ini memiliki desain observasional analitik untuk mengetahui apakah terdapat hubungan antara ekspresi HER2 dengan ukuran tumor dan invasi kapsular PTC. Penelitian dilakukan pada bulan Februari 2020 sampai September 2020. Tempat penelitian di Instalasi Patologi Anatomi RSUD Dr. Saiful Anwar Malang. Sampel yang digunakan adalah blok parafin dari kasus yang didiagnosis PTC di Instalasi Patologi Anatomi, dan terdapat kapsul thyroid periode waktu 01 Januari 2018 sampai dengan 31 Januari 2020. Kriteria eksklusi sampel adalah kualitas sediaan pemotongan ulang blok parafin menghasilkan pulasan imunohistokimia yang kurang baik, terdapat bagian melipat $>20 \%$ area jaringan atau diameter kurang dari $0,5 \mathrm{~cm}$ pada sediaan biopsi dan parafin blok yang hanya tersisa sangat sedikit jaringan $(<3 \mathrm{~mm})$.

Sampel yang representatif sesuai rumus besar sampel dengan koefisien korelasi $(r=$ 0,4 ), memenuhi kriteria inklusi dan kriteria eksklusi adalah 54 sampel. Jumlah sampel pada kelompok tanpa invasi kapsular dan invasi kapsular masing masing sebesar 27 sampel. Seluruh kasus dilakukan evaluasi besar tumor makroskopis dari rekam medis dan baca ulang secara mikroskopis. Komponen histopatologi yang dievaluasi ulang adalah invasi kapsular, subtipe histologi, metastase KGB dan besar tumor yang secara makroskopis meragukan. Penelitian ini telah mendapat persetujuan dari Komisi Etik Penelitian Kesehatan RSUD. Dr. Saiful Anwar dengan nomor: 400/108/ K.3/302/2020,

\section{Pulasan Immunohistokimia HER2}

Blok parafin dari kasus yang telah dibaca ulang dilakukan pemotongan menggunakan mikrotom dengan ketebalan 4 $\mu \mathrm{m}$. Jaringan yang sudah dipotong tersebut diletakkan pada slide kaca yang sudah dilapisi dengan poly-L-Lysine, kemudian dilakukan deparafinisasi dengan memasukkan ke dalam larutan xylol dan alkohol dengan konsentrasi menurun. Selanjutnya direndam ke dalam peroxide block solution selama 25 menit dilanjutkan dengan larutan DIVA sebelum dimasukkan ke dalam alat decloacking chamber pada suhu $90{ }^{\circ} \mathrm{C}$ selama 45 menit. Pemulasan diteruskan dengan direndam pada larutan PBS selama 5 menit, lalu diinkubasikan antibodi primer rabbit anti-human c-erb-2/HER2 clone EP3 (Biocare medical ACA 342), dilusi 1:150 selama 60 menit, kemudian dilakukan pemberian polymer. Langkah selanjutnya ialah pemberian $D A B$ chromogen dan pemulasan counter staining menggunakan hematoksilin selama 2 menit dan lithium karbonat. Proses berikutnya ialah clearing ke dalam larutan xylol yang kemudian dilanjutkan mounting. Pulasan kontrol positif menggunakan sediaan blok karsinoma mammae yang telah terdiagnosa HER2 positif (skor 3+).

\section{Evaluasi Ekspresi HER2}

Penghitungan ekspresi HER menggunakan mikroskop cahaya, dilakukan oleh 2 ahli patologi dan 1 peneliti menggunakan mikroskop CX23. 
Dihitung sel yang terpulas coklat pada membran sel tumor pada lapang pandang besar (x40) secara menyeluruh. Intrepretasi HER2 dinilai berdasarkan skor HER2 ASCO 2018, yaitu skor 0 (ekspresi HER2 tidak terdeteksi atau terpulas positif pada $<10 \%$ sel tumor), skor 1+ (ekspresi HER2 terpulas lemah pada $<10 \%$ sel, dan pada sebagian dari membran), skor 2+ (ekspresi HER2 terpulas kuat komplit pada membran sel dengan intensitas kuat pada $<10 \%$ sel tumor dan terpulas pada membran sel secara komplit dengan intensitas lemah sedang pada $>10 \%$ sel tumor), dan skor $3+$ (ekspresi HER2 terpulas pada membran sel secara komplit dengan intensitas kuat pada $>10 \%$ sel tumor). ${ }^{12}$

\section{Analisis Statistik \\ Hasil-hasil parameter dianalisis menggunakan SPSS version 2664 bit dengan melakukan uji beda Mann Whitney antara kelompok dengan invasi kapsular dan tanpa invasi kapsular terhadap skor HER2 untuk mengetahui hubungan antara ekspresi HER2 dengan invasi kapsular PTC. Analisa hubungan ukuran tumor dengan ekspresi HER2 menggunakan uji korelasi Spearman's. Perbedaan ekspresi yang diukur menggunakan masukan data berupa data ordinal nilai scoring berdasarkan ASCO 2018 sel yang terpulas HER2 pada sampel. Ukuran}

tumor berupa data numerik dalam satuan $\mathrm{cm}$. Invasi kapsular dinilai secara mikroskopis adanya invasi tumor yang menembus kapsul tiroid.

\section{Hasil}

\section{Karakteristik Sampel}

Penelitian ini dilakukan pada 54 sampel dari pasien yang didiagnosis PTC dengan varian dan stadiumnya. Pada stadium dicantumkan ukuran tumor, invasi kapsular tiroid, infiltrasi sel tumor pada otot sekitar dan metastase. Selain menilai ekspresi HER2, penelitian ini juga menilai ukuran tumor dan invasi kapsular tumor pada kapsul tiroid. Pada Gambar 1 memperlihatkan gambaran mikroskopis PTC dengan invasi kapsular dan PTC tanpa invasi kapsular pada sampel penelitian dengan pewarnaan $\mathrm{HE}$.

Secara histopatologi, varian/subtipe dari PTC terdiri dari 15 subtipe, yaitu ocult, classic, follicullar, difuse sclerosing, tall cell, encapsulated, cribriform morular, hobnail, with fasciiitis like stroma, solid, oncocytic, spindle cell, clear cell, collumnar, dan warthin -like. Namun, pada penelitian ini hanya didapatkan 7 subtipe PTC, yaitu classic, solid, follicular, encapsulated, collumnar, dan oncocytic. Pada Gambar 2 memperlihatkan subtipe histologi dari PTC dan metastase PTC pada KGB.

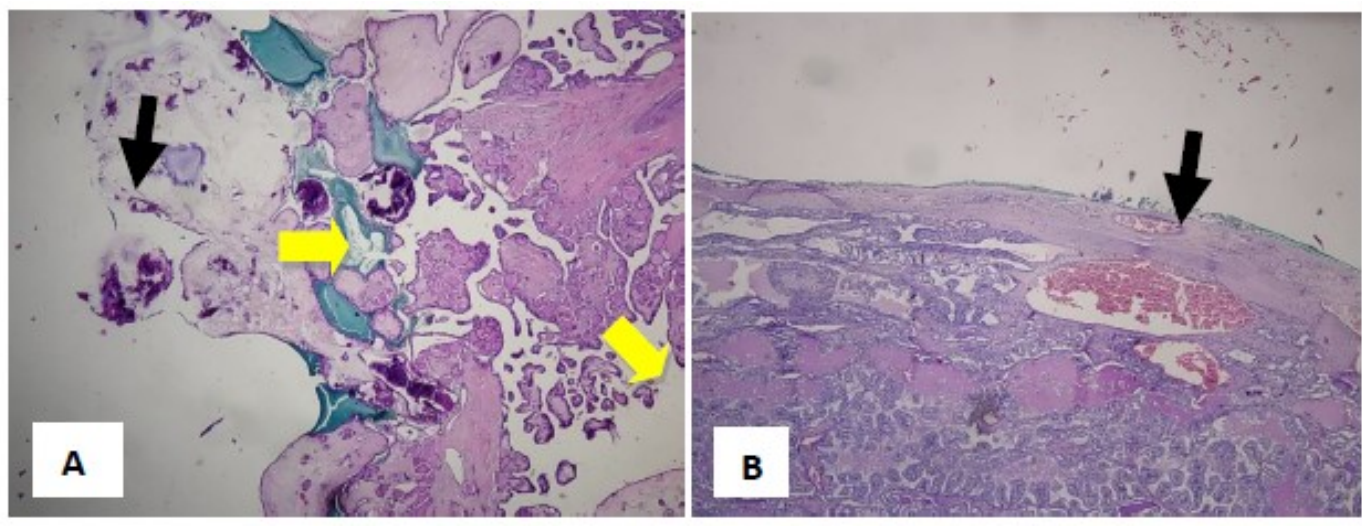

Gambar 1. Mikroskopis invasi kapsular PTC dengan pewarnaan HE.

Keterangan : Tanda panah kuning ( $)$ menunjukkan PTC, Tanda panah hitam $(\mathbf{Y})$ menunjukkan kapsul PTC. A) PTC dengan invasi tumor pada kapsul tiroid tiroid (100x), B) PTC yang tidak terdapat invasi tumor pada kapsul tiroid tiroid (100x). 


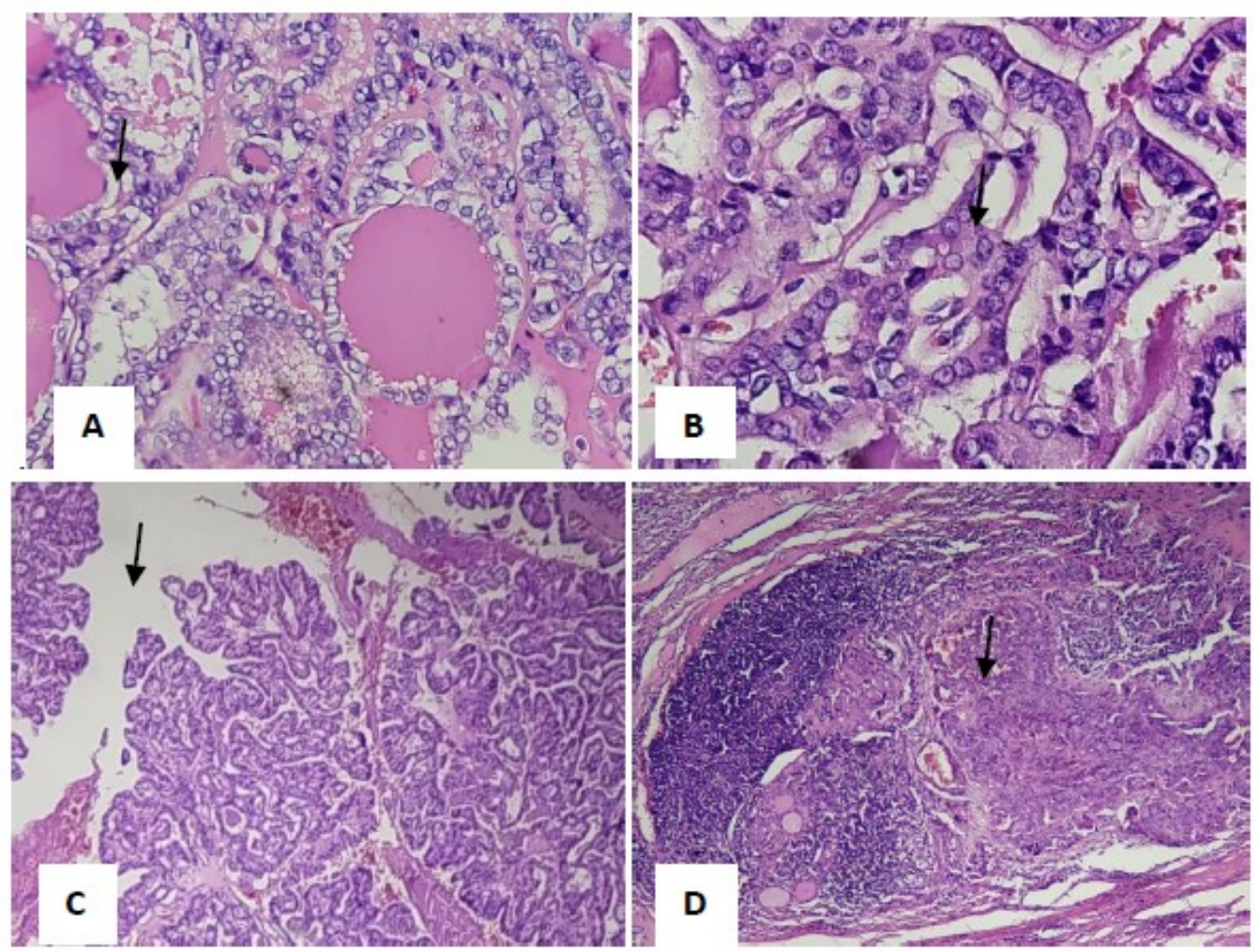

Gambar 2. Gambaran histologi subtipe PTC dan metastase PTC pada KGB dengan pewarnaan $\mathrm{HE}$.

Keterangan: Tanda panah ( $\downarrow$ ) menunjukkan tumor PTC. A) PTC subtipe follicular, terdapat folikel-folikel dilapisi sel berinti oval dengan ground glass appearance, intranuclear inclusion dan groove (400x); B) PTC subtipe solid, sel sel tumor tersusun trabekular dan solid (400x); C) PTC subtype classic,sel-sel tumor yang tersusun papiler (100x); D) Metastase PTC subtipe folikular pada KGB (100x).

Pada penelitian ini didapatkan 54 sampel dari tahun 2018 sampai dengan 2020.

Terdapat 27 sampel mengalami invasi kapsular dan 27 sampel tanpa invasi kapsular. Dari 54 sampel tersebut, didapatkan 42 sampel wanita (78\%) dan 12 pria (22\%). Rentang usia sampel penelitian berkisar 13 tahun sampai dengan 69 tahun, dengan usia terbanyak $>45$ tahun. Ukuran sampel penelitian berkisar antara 0,4-16 cm dengan rerata $\pm 4,7 \mathrm{~cm}$. Subtipe histologi PTC terbanyak adalah klasik (65\%). Pada Tabel 1 dapat diketahui karakteristik klinikopatologi serta persentase karakter klinikopatologi pada PTC dengan invasi kapsular dan tanpa invasi kapsular dengan pembagi jumlah seluruh sampel yaitu 54 .

\section{Ekspresi HER2}

Ekspresi HER2 yang ditampilkan pada Gambar 3 dinilai menggunakan scoring ASCO 2018, dengan kontrol HER2 3+ karsinoma payudara. Penilaian ekspresi HER2 terdiri dari negatif, equivocal, dan positif. HER2 negatif terdiri dari skor 0 dan $1+$, HER2 negatif dengan skor 0 apabila tidak terdapat pulasan HER2 pada membran sel tumor atau terpulas inkomplit kurang dari $10 \%$. Negatif dengan skor 1+ bila didapat pulasan HER2 inkomplit lebih dari 10\% membran sel tumor. HER2 equivocal (skor $2+)$ bila terpulas sedang kuat secara komplit, namun kurang dari $10 \%$ membran sel tumor atau terpulas lemah komplit pada membran sel tumor. Pada HER2 positif dengan skor 3+, bila HER2 terekspresi kuat komplit pada lebih dari $10 \%$ membran sel tumor. ${ }^{12}$ 
Tabel 1. Karakter klinikopatologi sampel penelitian

\begin{tabular}{lccc}
\hline Karakter Klinikopatologi & $\begin{array}{c}\text { Invasi } \\
\text { Kapsular }\end{array}$ & $\begin{array}{c}\text { Tanpa Invasi } \\
\text { Kapsular }\end{array}$ & $\begin{array}{c}\text { Sampel } \\
\text { Keseluruhan }\end{array}$ \\
\hline Umur (tahun) & 7 & & $20(37 \%)$ \\
$<45$ & 20 & 13 & $34(63 \%)$ \\
$>45$ & $22-67$ & 14 & $13-69$ \\
Rentang Usia & 49 & $13-69$ & 45 \\
$\quad$ Mean & & 41 & $12(22 \%)$ \\
Jenis Kelamin & 10 & 2 & $42(78 \%)$ \\
$\quad$ Pria & 17 & 25 & 1 \\
$\quad$ Wanita & 0 & 1 & 3 \\
Subtipe: Invasif encapcasulated & 2 & 1 & 12 \\
Solid & 4 & 8 & 1 \\
Folikular & 1 & 0 & 1 \\
Onkositik & 1 & 0 & 35 \\
Kolumnar & 0 & 1 & \\
Occult & 19 & 16 & $0,4-16$ \\
Klasik & & & 4,7 \\
Ukuran tumor (cm) & $0,9-16$ & $0,4-10$ & 4,5 \\
$\quad$ Rentang ukuran & 5,2 & 4,2 & \\
Mean & 3 & 4 & \\
Modus & &
\end{tabular}

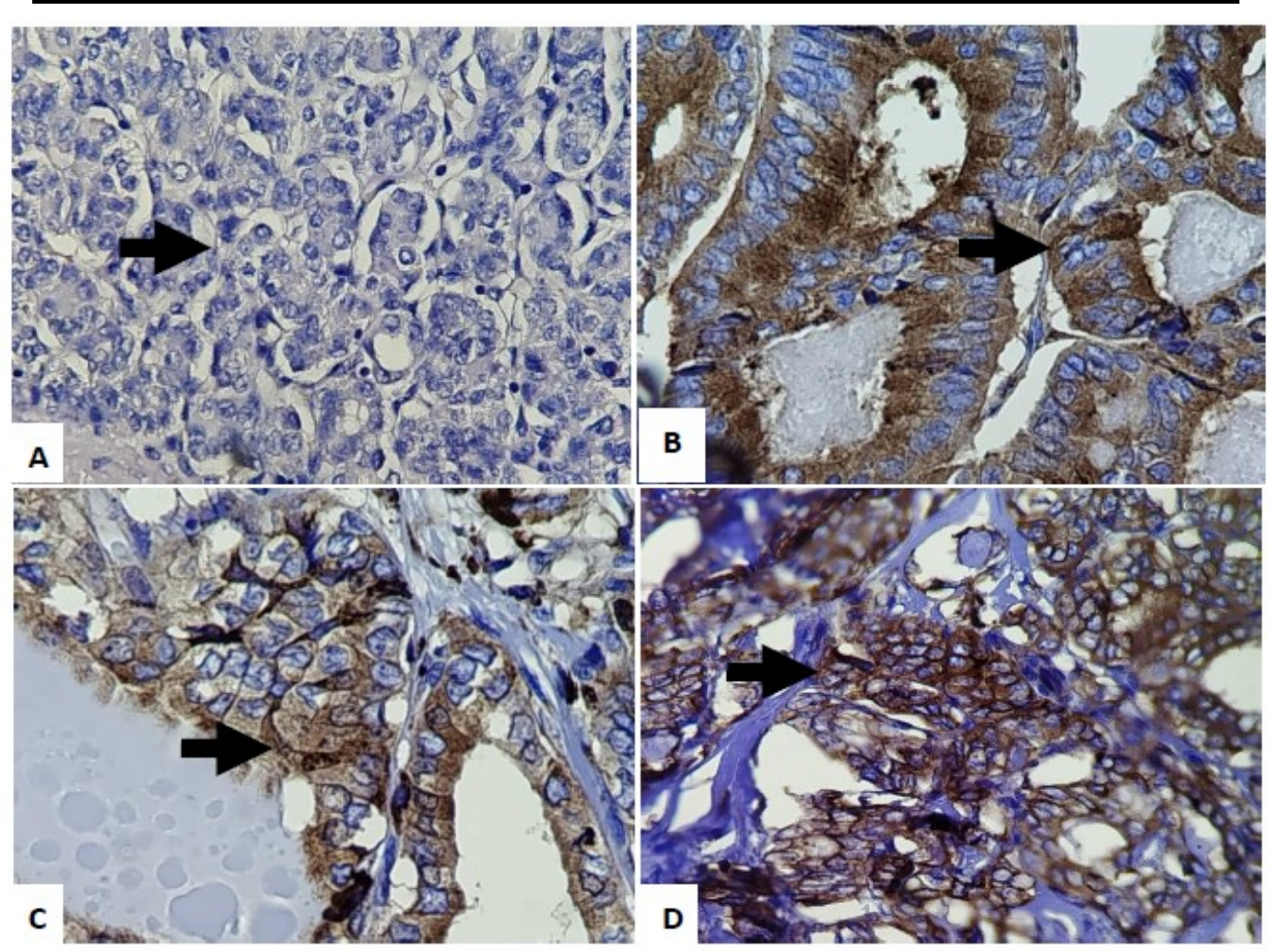

Gambar 3. Hasil pemeriksaan imunohistokimia ekspresi HER2 pada sampel penelitian.

Keterangan: Tanda panah $(\rightarrow)$ menunjukkan ekspresi HER2 pada membran sel PTC. A). PTC HER2 negatif (Skor 0), HER2 tidak terpulas pada membran sel; B). PTC HER2 negatif (Skor 1+), HER2 terpulas inkomplit sedang-kuat pada $>10 \%$ membran sel tumor; C). PTC HER2 equivocal (skor 2+), HER2 terpulas komplit sedang-kuat pada $<10 \%$ membran sel tumor; D). PTC HER2 positif (skor $3+$ ), HER2 terpulas komplit sedang-kuat $>10 \%$ membran sel tumor. 


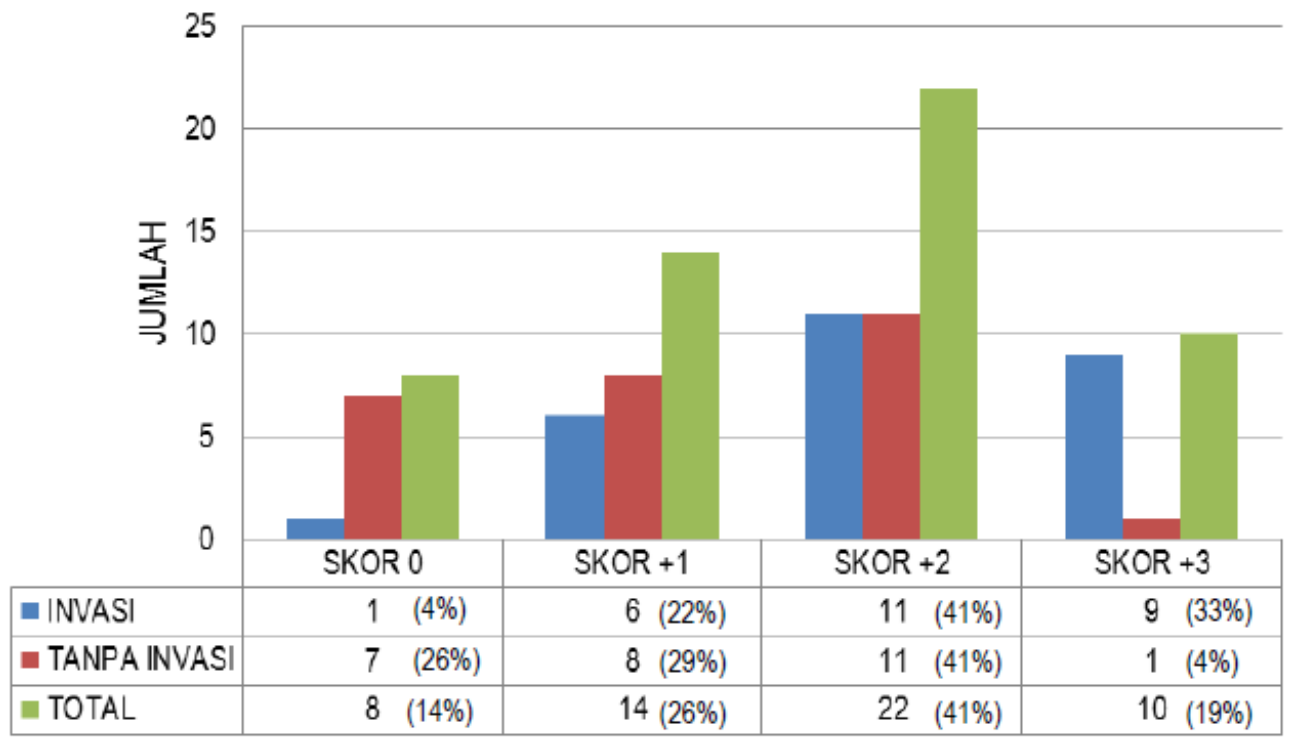

Gambar 4. Ekspresi HER2 pada PTC.

Keterangan: Skor 0 = PTC dengan ekspresi HER2 skor 0; Skor +1 = PTC dengan ekspresi HER2 skor +1; Skor+2 = PTC dengan wkspresi HER2 skor +2; Skor+3 = PTC dengan ekspresi HER2 skor +3. Skor HER2 dinilai berdasarkan ASCO 2018.

Pada Gambar 4 menunjukkan grafik ekspresi HER2 pada PTC dengan invasi kapsular, tanpa invasi kapsular, dan seluruh sampel. Ekspresi HER2 terbanyak pada kelompok invasi kapsular, tanpa invasi kapsular dan seluruh sampel adalah skor +2 (equivocal) sebesar $41 \%$. HER2 positif (skor +3) pada penelitian ini sebanyak 10 sampel (19 \%), terbanyak pada kelompok PTC dengan invasi kapsular (9 sampel).

Hubungan antara Ekspresi HER2 dengan Invasi Kapsular PTC

Hubungan antara ekspresi HER2 dengan invasi kapsular PTC dianalisis dengan uji beda Mann Whitney. Analisis ini membandingkan skor HER2 antara kelompok dengan invasi kapsular dan tanpa invasi kapsular. Penghitungan ekspresi HER2 dikatakan terdapat perbedaan bermakna jika nilai $p<0,05$. Berdasarkan hasil uji Mann Whitney, ekspresi HER2 menunjukkan adanya perbedaan yang bermakna antara kelompok dengan invasi kapsul dan tanpa invasi kapsular $(p=0,02)$, maka dapat disimpulkan terdapat hubungan antara ekspresi HER2 dengan invasi kapsular PTC.

Hubungan antara Ekspresi HER2 dengan Ukuran Tumor

Analisis hubungan antara ekspresi HER2 dengan ukuran tumor menggunakan uji korelasi Spearman. Hasil uji korelasi Spearman diperoleh koefisien korelasi -0,299 dan nilai $p$ (2 tail) 0,028 . Hal ini menunjukkan adanya hubungan rendah (koefisien korelasi 0,2-0,39) antara ekspresi HER2 dengan ukuran tumor, dan menunjukkan hubungan yang terbalik (semakin besar ukuran, scoring semakin rendah, yang ditunjukkan dengan 0.299). Nilai $p=0,028(p<0,05)$ dikatakan bermakna, meskipun terdapat hubungan yang rendah.

\section{Pembahasan}

Penelitian ini menggunakan 54 sampel dengan jenis kelamin terbanyak adalah wanita $(78 \%)$, hal ini sesuai dengan data epidemiologi dan penelitian sebelumnya yang mengemukakan bahwa insiden tersering PTC pada wanita. 3,4,12, 14 
Namun, usia terbanyak pada penelitian ini lebih dari 45 tahun (63\%). Hal tersebut tidak sesuai dengan data epidemiologi dan penelitian terdahulu bahwa pada wanita diketahui lebih sering terjadi pada usia muda dan usia di bawah 45 tahun.2,13,15 Pada penelitian Horn (2011) menyatakan adanya ketidakseimbangan hormon estrogen dan progesteron mempunyai peranan penting pada peningkatan risiko PTC pada wanita dengan usia menstruasi yang terlambat, siklus anovulatory dan siklus haid yang tidak teratur. Siklus haid yang memanjang dan haid yang terlambat secara independen terkait dengan tingginya kejadian PTC pada usia $<45$ tahun. ${ }^{15}$ Namun, pada sampel penelitian didapatkan terbanyak usia lebih dari 45 tahun, yang kurang sesuai dengan literatur. Pada penelitian Horn didapatkan data peningkatan risiko wanita usia lebih dari 45 tahun terkena PTC karena adanya riwayat terapi estrogen dan bukan terapi estrogen progesteron. ${ }^{14-17}$ Insiden PTC meningkat pada wanita post menopouse yang mendapat terapi estrogen. ${ }^{14-}$ 17, 20-22 Namun, data dari sampel penelitian tidak diketahui riwayat menstruasi dan terapi hormonal serta penggunaan alat kontrasepsi hormonan.

Subtipe PTC terbanyak didapatkan adalah tipe klasik atau konvensional, data ini juga sesuai dengan WHO (2017) bahwa varian klasik adalah varian yang paling sering ditemukan. ${ }^{4}$ Ukuran sampel berkisar antara 0,4 cm-16 cm, sesuai dengan WHO (2017) yang menyatakan ukuran tumor bervariasi. Pada PTC terdapat subtipe occult atau microcarcinoma yang berukuran $<10 \mathrm{~mm}$. Meskipun ada beberapa studi mengatakan bahwa peningkatan ukuran tumor berkaitan dengan agresifitas dan meningkatkan kemungkinan metastase pada KGB, namun pada PTC tidak selalu berhubungan. Seringkali tumor ditemukan bermetastase, tetapi primer tumor berukuran $<0,5 \mathrm{~cm} .{ }^{4,13}$

Ekspresi HER2 pada penelitian ini menggunakan skor berdasarkan ASCO 2018 dengan menilai positifitas HER2 pada membran sel tumor. Pada penelitian lain disebutkan bahwa skoring HER2 menggunakan kombinasi positifitas membran dan kuat tidaknya ekspresi, meskipun pada sitoplasma. Namun, pada neoplasma tiroid hanya HER2 dengan positifitas membran yang kemungkinan bermakna untuk terapi, sehingga banyak penelitian menggunakan skor positifitas membran seperti pada karsinoma payudara untuk intrepetasi ekspresi HER2 pada tiroid. Ekspresi HER2 pada PTC di penelitian ini yang terbanyak skor 2+ sebanyak 22 kasus $(41 \%)$. Kasus HER2 dengan skor 3 hanya 19\%. Hal ini sesuai dengan penelitian Rabiee dan Delia yang kurang dari sepertiga kasus HER2 positif.9,10 Pada HER2 skor 2+ masih diperlukan pemeriksaan Fluorescence in situ Hybridization (FISH) untuk menentukan positifitas HER2 pada tumor. Pemeriksaan FISH digunakan untuk konfirmasi status HER2 equivocal (skor 2+) yaitu untuk menentukan bahwa tumor tersebut mengekspresikan dengan kuat terhadap HER2. FISH untuk reseptor HER2 umumnya digunakan pada kanker payudara. Pada penelitian Sugishita (2013) mengemukakan bahwa terdapat korelasi antara pemeriksaan imunohistokimia HER2 dengan FISH positif gen HER2 pada karsinoma thyroid yang berdiferensiasi, di antaranya PTC. Sehingga skor ekspresi HER2 pada PTC dapat dinilai seperti penilaian pada karsinoma payudara, dan kemungkinan memiliki peluang terhadap terapi tranztuzumab. ${ }^{19}$

Pada penelitian ini terdapat perbedaan yang bermakna terhadap ekspresi HER2 pada kelompok dengan invasi tumor pada kapsul tiroid dan tidak. Hal ini sesuai dengan penelitian sebelumnya bahwa pada kelompok berisiko tinggi (>45 tahun), lebih banyak terjadi invasi kapsular. Ekspresi positifitas HER2 juga berhubungan dengan invasi kapsular. 
Pada penelitian ini kebanyakan berusia lebih dari 45 tahun, dan terdapat hubungan bermakna antara positifitas HER2 dengan invasi kapsular. Serta didapatkan rerata nilai skor HER2 yang lebih tinggi pada kelompok dengan invasi kapsular dan tidak. ${ }^{8-11}$ Namun, penelitian lebih lanjut dibutuhkan karena besarnya HER2 yang bernilai equivocal perlu dikorelasikan dan dilanjutkan dengan pemeriksaan FISH.

Pada penelitian ini terdapat hubungan yang bermakna dengan korelasi negatif yang lemah antara ekspresi HER2 dengan ukuran tumor yaitu semakin besar tumor semakin kecil scoring HER2. Hal ini bertentangan dengan penelitian Rabiee dan Mohapatra (2017), yang berbanding lurus/positif, serta menyimpulkan tidak ada hubungan yang jelas antara ukuran tumor dan ekspresi HER2 6,7. Selain itu, pada data Mohapatra dan Rabiee sampel lebih banyak pada usia $<45$ tahun, berbeda dengan sampel penelitian ini yang lebih banyak pada usia $>45$ tahun. ${ }^{8,9}$

Beberapa penelitian telah dilakukan untuk mengkaji apakah ekspresi HER2 berhubungan dengan faktor prognosis PTC. Namun, masih terdapat kontroversi apakah HER2 memiliki peranan dalam menentukan faktor prognostik. Pada penelitian Cau, Rabie, Caria, Delia dan Mohapatra menyebutkan bahwa terdapat hubungan antara ekspresi HER2 dengan faktor prognostik. 8-10,18,22 Sementara pada penelitian Balta dan Kim menyatakan tidak ada hubungan antara ekspresi HER2 dengan faktor prognostik. 6,7

Perbedaan ekspresi HER2 dipengaruhi oleh kualitas preanalitik sampel, reagen, profil sampel dan profil molekuler yang dimiliki tumor tersebut. Kekurangan beberapa penelitian terdahulu tidak semua menyebutkan secara jelas metode penelitian, profil, usia sampel terbanyak, dan jenis reagen yang digunakan. Studi kasus yang dilakukan oleh Gao (2014) pada 3 pasien dengan kasus metachronous kanker payudara HER2 positif menunjukkan adanya PTC setelah terdiagnosa kanker payudara dengan HER2 positif. Gao (2014) menyimpulkan bahwa HER2 menunjukkan sifat agresifitas tumor, dan pasien payudara dengan HER2 positif merupakan faktor risiko terjadinya PTC. ${ }^{23}$ Pada penelitian Yoshisuki (2012) menyebutkan bahwa telomere pada PTC lebih pendek dibanding HER2 negatif, yang berpengaruh pada agresifitasnya dan efektifitas terapi tranztuzumab. ${ }^{18} \mathrm{Hal}$ itu diperkuat oleh penelitian Caria (2016) yang menyatakan bahwa terdapat hubungan antara amplifikasi HER2 pada pemeriksaan FISH dengan mutasi BRAFV600E dan pemendekan telomere. Hal tersebut bisa menjadi penanda agresifitas dan pada kasus PTC yang refrakter, mempunyai peluang sebagai target terapi tranztuzumab. ${ }^{24}$

Alqaisi pada tahun 2014 menyebutkan koekspresi HER2 pada ER hanya berhubungan dengan tumor dengan grade dan TNM yang lebih tinggi, usia muda. ER positif pada pasien usia tua dan grade yang rendah, tidak berhubungan dengan ekspresi HER2.25 Mishra (2020) dan Dai (2017) menyatakan terdapat hubungan antara ekspresi HER2 dan ER dengan faktor prognosa PTC seperti ukuran tumor dan invasi kapsular. Namun, penelitian tersebut tidak menyebutkan profil usia sampel terbanyak. ${ }^{11,22}$ Sehingga tidak dapat dijelaskan hubungan peningkatan ukuran tumor dan invasi kapsular dengan ekspresi HER2 dan ER berkaitan dengan karakteristik usia sampel terbanyak.

Penelitian ini tidak dapat menjelaskan lebih lanjut mengenai profil molekuler dan hormonal yang dimiliki sampel penelitian ini karena keterbatasan sarana. Data profil klinis sampel pada penelitian ini juga kurang lengkap karena hanya mengambil data dari rekam medis yang sangat tergantung pada isian formulir patologi anatomi. 
Sehingga tidak dapat diketahui terapi apa saja yang telah diterima pasien, status paparan hormonal pasien dan riwayat pasien terdahulu dan progesifitas tumor.

\section{Kesimpulan}

Pada penelitian menunjukkan terdapat hubungan ekspresi HER2 dengan invasi kapsular PTC, serta diketahui adanya hubungan lemah berbanding terbalik antara ekspresi HER2 dengan ukuran tumor, yang artinya semakin besar tumor semakin rendah skor HER2 atau sebaliknya.

\section{Saran}

Penelitian mengenai ekspresi HER2 pada PTC perlu dilakukan lebih lanjut dilengkapi dengan FISH untuk memastikan positifitas HER2 skor 2+ pada PTC. Pada penelitian yang mengevaluasi faktor penentu keganasan lain seperti paparan hormonal, angioinvasi, metastase pada PTC juga masih perlu dilakukan untuk dapat menunjang faktor prognostik maupun proses diagnostik. Selain itu, HER2 dapat diteliti lebih lanjut peranannya sebagai target terapi obat neoplasma pada kasus PTC diperlukan untuk penatalaksanaan pasien PTC.

\section{Daftar Pustaka}

1. Siegiel $R$, Miller $K$, Jemal $A$. Cancer Statistics, 2017. CA Cancer J Clin. 2017; 67(1):7-30.

2. Howlader NN, Noone AM, Krapcho ME, Miller D, Brest A, Yu M, Ruhl J, Tatalovich Z, Mariotto A, Lewis DR, Chen HS. SEER Cancer Statistics Review, 1975-2016. Bethesda, MD: National Cancer Institute. 2019. P. 1423-37.

3. Badan Registrasi Kanker. Yayasan Kanker Indonesia. 2014

4. Lloyd RV, Osamura RY, Klöppel G, Rosai $\mathrm{J}$. WHO Classification of Tumours of
Endocrine Organs. International Agency for Research on Cancer. 2017.

5. Iqbal N, lqbal N. Human Epidermal Growth Factor Receptor 2 (HER2) in Cancers: Overexpression and Therapeutic Implications. Molecular Biology International. 2014; 2014: 852748. doi: 10.1155/2014/852748.

6. Balta AZ, Filiz AI, Kurt Y, Sucullu I, Yucel E, Akin ML. Prognostic Value of Oncoprotein Expressions in Thyroid Papillary Carcinoma. Medical Oncology. 2012; 29(2):734-41.

7. Kim YS, Kim JS, Kim YS. EGFR and HER2 Expression in Papillary Thyroid Carcinoma. Journal of Endocrine Surgery. 2018; 18(4):228-35.

8. Mohapatra D, Das D, Hota A. Correlation between Her2/Neu Oncoprotein Expression and Prognostic Factors in Papillary Thyroid Carcinoma. Journal of Medical Science and Clinical Research. 2019; 7(2):271-276.

9. Rabiee S, Nadoushan MJ, Rayeni NM, Ansari I. Correlation between Human Epidermal Growth Factor Receptor 2 Oncoprotein Expression and Some Prognostic Factors in Papillary Thyroid Carcinoma. Indian Journal of Pathology and Microbiology. 2017; 60(3):324.

10. Apostol DC, Caruntu ID, Lozneanu L, Andriescu EC, Giusca SE. Her-2/Neu Expression in Different Histological Subtypes of Papillary Thyroid Carcinoma. Rom J Morphol Embryol. 2017; 58(2):43944.

11. Mishra A, Kumari N, Jha CK, Bichoo RA, Mishra SK, Krishnani N, Mishra SK. Distribution and Prognostic Significance of Estrogen Receptor a $(E R a)$, Estrogen Receptor $\beta$ (ERß), and Human Epidermal Growth Factor Receptor 2 (HER-2) in Thyroid Carcinoma. Journal of Thyroid Research. 2020; 2020.6935724. doi: 10.1155/2020/6935724. 
12. Wolff AC, Hammond ME, Allison KH, Harvey BE, Mangu PB, Bartlett JM, Bilous M, Ellis IO, Fitzgibbons P, Hanna W, Jenkins RB. Human Epidermal Growth Factor Receptor 2 Testing in Breast Cancer: American Society of Clinical Oncology/College of American Pathologists Clinical Practice Guideline Focused Update. Archives of Pathology \& Laboratory Medicine. 2018; 142 (11):1364-82.

13. Edward P. New Trends in Tiroid Cancer - a True Incidence Rise or OverDiagnosis?. (Online). 2018. www.hannover-re.com.

14. Kilfoy BA, Devesa SS, Ward MH, Zhang $Y$, Rosenberg PS, Holford TR, Anderson WF. Gender is an Age-Specific Effect Modifier for Papillary Cancers of the Thyroid Gland. Cancer Epidemiology and Prevention Biomarkers. 2009; 18 (4):1092-100.

15. Horn-Ross PL, Canchola AJ, Ma H, Reynolds P, Bernstein L. Hormonal Factors and the Risk of Papillary Thyroid Cancer in the California Teachers Study Cohort. Cancer Epidemiology and Prevention Biomarkers. 2011; 20 (8):1751-9.

16. Derwahl M, Nicula D. Estrogen and Its Role in Thyroid Cancer. EndocrineRelated Cancer. 2014; 21(5):T273-83.

17. Moleti M, Sturniolo G, Di Mauro M, Russo M, Vermiglio F. Female Reproductive Factors and Differentiated Thyroid Cancer. Frontiers in Endocrinology. 2017; 8:111.

18. Qin C, Cau W, Zhang Y, Mghanga FP, Lan X, Gao Z, An R. Correlation of Clinicopathological Features and Expression of Molecular Markers with Prognosis after 1311 Treatment of Differentiated Thyroid Carcinoma. Clinical Nuclear Medicine. 2012; 37 (3):e40-6.

19. Sugishita $Y$, Kammori M, Yamada O, Poon SS, Kobayashi M, Onoda N, Yamazaki K, Fukumori T, Yoshikawa Kl, Onose $\mathrm{H}$, Ishii $\mathrm{S}$. Amplification of the Human Epidermal Growth Factor Receptor 2 Gene in Differentiated Thyroid Cancer Correlates with Telomere Shortening. International Journal of Oncology. 2013; 42(5):158996.

20. Przybylik-Mazurek E, HubalewskaDydejczyk A, Fedorowicz A, Pach D. Factors Connected with the Female Sex Seem to Play an Important Role in Differentiated Thyroid Cancer. Gynecological Endocrinology. 2012; 28 (2):150-5.

21. Caini S, Gibelli B, Palli D, Saieva C, Ruscica M, Gandini S. Menstrual and Reproductive History and Use of Exogenous Sex Hormones and Risk of Thyroid Cancer among Women: a MetaAnalysis of Prospective Studies. Cancer Causes \& Control. 2015; 26(4):511-8.

22. Dai YJ, Qu YB, Jiang R, Xu M, Zhao L, Chen GG, Liu ZM. Concomitant High Expression of ERa36, EGFR and HER2 is Associated with Aggressive Behaviors of Papillary Thyroid Carcinomas. Scientific Reports. 2017; 7(1):1-0.

23. Gao $Q$, Zheng $Y$, Wang $B$, Wu Z, Ren $G$. Three Metachronous Cases of HER2Positive Breast Cancer Accompanied with Thyroid Cancer. Breast Care. 2014; 9(5):360-3.

24. Caria P, Cantara S, Frau DV, Pacini F, Vanni R, Dettori T. Genetic Heterogeneity of HER2 Amplification and Telomere Shortening in Papillary Thyroid Carcinoma. International Journal of Molecular Sciences. 2016; 17 (10):1759. 
25. Alqaisi A, Chen L, Romond E, Chambers M, Stevens M, Pasley G, Awasthi M, Massarweh S. Impact of Estrogen Receptor (ER) and Human Epidermal Growth Factor Receptor-2 (HER2) Co-Expression on Breast Cancer Disease Characteristics: Implications for Tumor Biology and Research. Breast Cancer Research and Treatment. 2014; 148(2):437-44. 